\title{
Herbert Hoover's Technical Mission to Yugoslavia, 1919-20*
}

Gary Dean Best

ON FEBRUARY 24, 1919, Congress appropriated $\$ 100$ million for the purpose of furnishing relief to neutral nations and to those new nations which had been formed from the disintegration of the Austrian and Russian empires. The money was provided as a working fund for a new organization established by Congress to maintain strict accountability of the money separately from other food and relief organizations. Herbert Clark Hoover was named director of the new organization, the American Relief Administration. Thus, the man who had directed the relief of Belgium and northern France before the war, and the U.S. Food Administration during the war, was now called upon to direct what he called America's "second intervention" in Europe-this one of American food to conquer starvation and sickness. ${ }^{1}$ Now he began what Professor Harris G. Warren has called "a preview of the later UNRRA, without the support of a United Nations." ${ }^{2}$ While

*Hoover's technical missions to eastern Europe, 1919-1923, have been largely neglected by historians. The only comprehensive study of any of the missions is Donald R. Van Patten, "The European Technical Advisers and Post-War Austria, 1919-1923," a two volume unpublished Ph.D. dissertation of Stanford University, 1943. The only mission to publish its report was the Barber mission to Poland. See A. B. Barber, Report of European Technical Advisers Mission to Poland, 1919.1922 (New York, 1925). The papers of the European Technical Advisers ( 72 boxes) are accessioned in the archives of the Hoover Institution on War, Revolution and Peace, Stanford, California:

The author acknowledges with gratitude the assistance received from the Hoover Presidential Library Association which made possible research for this article in 1972.

'Herbert Hoover, Memoirs (New York, 1951), I, 304.

${ }^{2}$ Harris G. Warren, Herbert Hoover and the Great Depression (New York, 1967), p. 23. 
his title was Director-General of Relief and Rehabilitation under the Paris Peace Conference, in effect his operation was almost wholly an American Relief Administration effort, and those who made it work throughout Europe were in many cases old Hoover hands from the CRB and the Food Administration, some of them now in uniform but loaned to Hoover by the armed forces for as long as he might have need of them.

Relief was not alone a matter of procuring needed food supplies. It soon developed that one major problem to be overcome was that of transporting the supplies to the place of need once they had reached European ports. As Hoover recalled in his memoirs years later, the railroads of the whole of central and eastern Europe "were in chaos," and the situation was made worse by the newness of the national boundaries in the area. ${ }^{3}$ The railroads that had been consolidated under three empires were now chopped up into eighteen different railroad systems under as many jealous and often hostile governments. Thus, Hoover was forced to organize a Transportation Section which sent experienced American railway men to work with each of the governments in coordinating the movement of railway equipment across national boundaries with the guarantee of the Transportation Section that they would not be lost to the government which owned them. ${ }^{4}$

The American Relief Administration established by Congress in connection with the $\$ 100$ million appropriation came to an end with the expiration of its authority on June 30,1919, but the need for a relief and rehabilitation agency like it continued. Thus, the old American Relief Administration was replaced by a "new" American Relief Administration-a private relief organization by that name formed on July 12 th and registered as a non-profit corporation. Hoover presided over the new organization as chairman, with such Hoover food and relief veterans as Julius $H$. Barnes, Edgar Rickard, William A. Glasgow, and others on the board of directors. ${ }^{3}$ While the new organization had no official standing it did enjoy the confidence not only of the American government, but of the European governments as well, and it assumed responsibility for the distribution of the remaining food

${ }^{3}$ Hoover, Memoirs, I, 310-320.

${ }^{4}$ Loc. cit.

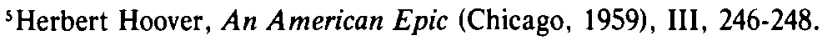


acquired with the funds provided by the Congressional appropriation and from other sources. As the old ARA and the U.S. Grain Corporation withdrew from the various countries in Europe, the new ARA took over their functions, their offices and equipment, while continuing their work without a break in the relief program. ${ }^{\circ}$

When the withdrawal of the old ARA from eastern Europe called for the departure of the transporation experts assigned to the governments there, some indicated their desire to Hoover that this kind of assistance should be continued for some time after the signing of the peace. Hoover's ARA had been the agency for all monetary exchange transactions between the United States and these nations during the armistice, and from those transactions had various amounts of money which had accumulated to the credit of those nations. ${ }^{7}$ He now suggested to the governments of Austria, Poland, Czechoslovakia and Yugoslavia that they authorize him to retain the necessary funds from these accounts and, in his capacity as trustee, to appoint technical advisers appropriate to the needs of the various countries. Poland and Austria accepted at once, Czechoslovakia and Yugoslavia somewhat later. ${ }^{8}$

In the case of Yugoslavia, the proposal was first suggested to that government through Professor M. I. Pupin, a Columbia University professor of Serb descent. On July 11 th Hoover suggested the plan to him verbally and followed it up with a letter the same day. Hoover wrote that it appeared to him that Yugoslavia was "in vital need of securing an eminent American Engineer with a few assistants to act as the transportation adviser of the Government." Aside from his intrinsic value to the Yugoslav Government, he would also be of great assistance in at least five other areas. He would be useful in obtaining railway materials and railway financing from the United States; his knowledge of American

\footnotetext{
'Frank M. Surface and Raymond L. Bland, American Food in the World War and Reconstruction Period (Stanford, 1931), pp. 73-74.

'William B. Poland to Minister Grouitch, March 23, 1922, European Technical Advisers Papers, Hoover Institution on War, Revolution and Peace, Stanford, California, hereafter cited as ETA Papers. The Yugoslavs had a total of $\$ 323.000$ on deposit with the ARA, of which $\$ 150,000$ was subsequently directed to the technical advisers, the remainder to child feeding under the ARA.

${ }^{8} \mathrm{~J}$. W. Krueger, "The Origin and Development of the European Technical Advisers," ETA Papers, Krueger was assistant office manager in New York City.
} 
railway and manufacturing techniques would be of immense use to the Yugoslavs; he would be of great use in negotiating with surrounding governments and their railway administrations; since Yugoslavia must rid herself of "the domination of Austrian and Hungarian Engineers" who had formerly directed her railways, a disinterested group of American engineers would be useful until Yugoslavia's own personnel were more largely developed; and finally, he would be able to continue the useful work already begun under the Transportation Section of the ARA in these areas. It would be a simple matter, Hoover told the professor, to set aside enough money from the remittance funds to support the technical mission, and he would act as trustee for the payment of salaries during the forthcoming year. "Immediate decision on this matter is absolutely necessary," he wrote Pupin, "as these engineers will be returned to the United States to resume their old positions unless arrangements are set up at once."

When a reply was not immediately forthcoming, Colonel William Causey, soon to be technical adviser to Austria, wired an ARA representative in Belgrade describing Hoover's proposal and suggesting that he "place before the Serbian government at once the suggestion contained in this telegram and advise if they desire action taken on same." Prompt action was necessary, he said, since American personnel were leaving France very rapidly. ${ }^{10}$ Causey's messenger, an army major, was, however, kept waiting one and a half hours in the anteroom without an audience. "It would appear," wrote one Hoover associate, "that our assistance is not desired and it is humiliating to be begging to be allowed to give it." "Colonel William G. Atwood, whom Hoover proposed to employ as technical adviser to Yugoslavia, however, explained it differently. The Yugoslavs were not being impolite, he said, it was only that they have "so little ability to organize and so little competent personnel available that such happenings are not to be wondered at." 12 More likely the Yugoslavs were somewhat confused. The remittance funds, they were told, belonged to the Yugoslav Government. Now the American Relief Administration

\footnotetext{
${ }^{9}$ Hoover to Professor Pupin, July 11, 1919, ETA Papers.

${ }^{10}$ Quoted in Causey to William Atwood, July 14, 1919, ETA Papers.

"Thomas Gregory to Atwood, July 17, 1919, ETA Papers.

${ }^{12}$ Atwood to Causey, July 19, 1919, ETA Papers.
} 
proposed to spend the money in their behalf. But what if the $\mathrm{Yu}$ goslav Government sought to use the money for some other purpose? Hoover's wire to Colonel Causey was clear. The Yugoslavs could not use the remittance money "for other purposes than have our approval for specific use to be made of it." That approval, for the moment, centered on the technical adviser proposal and it was necessary that they take quick action since "only a few construction troops remain." To speed up a Yugoslav decision the amount to be made available for the technical mission was increased to $\$ 150,000$ from the $\$ 100,000$ originally proposed. ${ }^{13}$

On July 26th the technical adviser proposal was made formally through the U.S. Legation in Belgrade to the Yugoslav Foreign Office. ${ }^{14}$ The matter was finally put before the Yugoslav Council of Ministers on August 19th by the Minister of Communications. The technical advisers, he told the council,

would have as their mission to lend us their counsel and assistance in all questions touching the reconstruction and putting in order of our railways, in order that they may be given over to regular traffic; as well as in all questions regarding the reconstruction of our coal-mines; if that becomes necessary. The same experts would moreover co-operate in the organization of transport of material for the railways purchased by the Royal Government from the American Liquidation Commission in France; moreover they will also co-operate, in all future orders for railway material in America, putting us in touch, in this regard, with competent American experts; in the transport of this same material from the port to this country; in our relations with the banking establishments in America, by giving us all the necessary instructions on this subject. Finally, these experts will include in their mission the re-establishment of international traffic relations, principally with the newly formed states, a relation which is vitally necessary to our country, and which was however completely interrupted by the war.

The Minister of Communications added that Mr. Hoover had pointed out "that it is his own organization which is at present maintaining these international relations" and that a number of governments had requested that the service be continued. Therefore, Hoover had suggested, Yugoslavia might find it advisable to make the same decision, though he wanted to avoid any appearance of pressuring the Yugoslav Government to accept the services of such a mission. The Minister of Communications recommended acceptance of Hoover's proposal and the Council of Min-

${ }^{13}$ Hoover to Causey, July 17, 1919, ETA Papers.

${ }^{14}$ William G. Atwood, "Report of the Technical Mission of the Kingdom of the Serbs, Croats and Slovenes [Yugoslavia]," ETA Papers. 
isters accepted it on August 22, 1919. ${ }^{15}$ The Yugoslav acceptance of the proposition was, however, hedged with conditions-conditions which seem more to have been the result of their misunderstanding the full details of the proposition than anything else -and not until September 13th were the misunderstandings cleared away and the proposition agreed to in such a way as to be acceptable both to the Yugoslav Government and to Hoover and the ARA. ${ }^{16}$

Colonel William G. Atwood, who had been head of the Transporation Section of the American Relief Administration and the American member of the Communications Section of the Supreme Economic Council, was named chief technical adviser to the Yugoslav Government. Under Colonel Atwood were five other technical advisers, Colonel C. S. Coe, Captain C. E. McMillan, Captain J. H. Porter, Mr. J. H. Nelson, and Mr. H. I. Smith. All but Smith and Porter had sailed to Yugoslavia by the end of October, 1919. Atwood himself remained in the United States until the end of December carrying out the instructions of the Yugoslav Government relative to obtaining loans and supplies. The instructions set forth by the Yugoslav Council of Ministers assigned the technical advisers duties under seven categories:

1. To try to obtain a loan from the American government to pay for the shipment of supplies already purchased by the Yugoslav Government from the stocks of the United States Liquidation Board in France.

2. To obtain financing from the United States Government to cover the purchase of additional U.S. War Department material in the United States, and to pay for its shipment to Yugoslavia.

3. To co-operate with the technical advisers in other countries in reestablishing international transportation relations.

4. To advise the Ministry of Mines in the reopening of destroyed mines. the opening of new mines, and the securing of necessary materials from the United States to carry out these activities.

5. To assist the Ministry of Finance in securing loans from American bankers.

6. To advise the Ministry of Communications "in all matters pertaining to the construction, reconstruction and operation of railways."

7. To assist any other ministries desiring their aid. ${ }^{1 "}$

15The Minister of Communications, M. Drachkovitch, to the Council of Ministers, August 19, 1919, with endorsement of August 22, 1919, translation enclosed with H. Percival Dodge (U.S. Minister to Yugoslavia) to William Atwood, October 4, 1919, ETA Papers.

${ }^{16}$ Hoover to Dodge, September 2, 1919; Atwood to Dodge, September 8. 1919; Dodge to Atwood, September 13, 1919, ETA papers.

${ }^{17}$ Ibid. 
To assist the technical advisers in Yugoslavia, as well as those in Austria, Poland and Czechoslovakia, a liaison office was established in Paris under Colonel James A. Logan, Jr., who was also American representative on the European Coal Commission and temporary American representative on the interim Reparation Commission. The European Coal Commission was an independent commission arranged by Hoover before he left for the United States. It consisted of representatives of all the involved European nations and of the United States. Colonel H. C. Nutt became president and chairman of the European Coal Commission in September, 1919, with his salary paid from the remittance funds earmarked for the technical advisers of Austria, Poland and Czechoslovakia. In addition to the Paris liaison office, Edgar Rickard and William B. Poland were named as joint managers of the technical adviser operation and directed it from the ARA offices in New York City. The New York office, through its technical and business staff, was able to process inquiries from the technical advisers in behalf of the governments they represented, concerning such matters as the procurement of machinery, supplies and materials in the United States, from both private industrial concerns and the surplus supplies of the War Department, and also passed along to potential investors in the United States information furnished them by the technical advisers concerning possible mining, agricultural and industrial opportunities for development by American capital. ${ }^{18}$

Relations between the technical advisers and the Yugoslav Government were complicated by chronic political crises which resulted in frequent cabinet changes. The instability of the government clouded even the original acceptance of Hoover's proposal, as the cabinet making the agreement held only "a very small majority" and was not expected to last very long. ${ }^{19}$ It was not long after his arrival in Yugoslavia before Atwood was bemoaning the unsettled condition of political affairs-a situation which prevented "the formation of any permanent organizations in any of the Departments" with the results that "the temporary organizations existing do not have the authority or the cohesion

\footnotetext{
${ }^{18}$ Krueger, "Origin and Development," ETA Papers; Donald R. Van Patten, "The European Technical Advisers and Post-War Austria, 1919-1923," (unpublished Ph.D. dissertation. Stanford University, 1943), I. 295-300.

"Dodge to Hoover. August 24, 1919, ETA Papers.
} 
that they need for efficiency." ${ }^{20}$ In April and May of 1920 conditions became so bad that Atwood felt if the Cabinet then in power continued in office "our services are useless and not desired. . . ."21 In June conditions improved slightly with at least the Prime Minister and the Minister of Communications so that Atwood could report that all in the technical mission were "busy and happy" that month. ${ }^{22}$ There now seemed a possibility that the mission might be able to continue. In mid-June Atwood considered it "a bare possibility that they may want us to stay longer. ${ }^{23}$ However, the record of spotty relations with the Yugoslav Government was not encouraging to the New York office. As the $\$ 150,000$ allocated for the mission began to run low, the New York office advised Atwood that the technical mission "should be formally wound up not later than October first [1920], unless we have a specific communication in writing from the Prime Minister requesting us to continue. ..." Should this latter occur, the Yugoslav Government would have to provide the funds for the continuation of the technical mission through an appropriation of its own. ${ }^{24}$ Scarcely had Atwood received this instruction from the New York office before conditions again worsened, with the cabinet being voted out and governmental affairs reaching a standstill. ${ }^{25}$

During its brief tenure in Yugoslavia the technical mission did manage to accomplish some of the work assigned to it by the $\mathrm{Yu}$ goslav Government. The first of the duties assigned it was carried out in full. Mr. Hoover was able to secure permission from the United States Treasury to use up to $\$ 660,000$ of unexpended funds loaned to Yugoslavia, and then in the hands of the U.S. Grain Corporation, to pay for ocean freight on the material purchased by Yugoslavia from the United States Liquidation Board in France. ${ }^{26}$ In this case the contribution of the technical mission was utilized effectively, for the funds were subsequently used for the purpose intended. The second of the duties assigned to the technical mission, however, did not end so happily. While the technical mission, through the New York office, succeeded in ob-

${ }^{20}$ Atwood to Logan. March 1, 1920, ETA Papers.

21 Atwood to Poland, May 14, 1920. ETA Papers.

${ }^{22}$ Logan to New York Office, June 7, 1920, ETA Papers.

${ }^{23}$ Atwood to Poland, June 14, 1920, ETA Papers.

${ }^{24}$ Poland to Atwood, July 16, 1920, ETA Papers.

${ }^{25}$ Atwood to Poland, July 24, 1920. ETA Papers.

${ }^{20}$ Norman O. Davis to Hoover, November 21. 1919. ETA Papers. 
taining a $\$ 25$ million credit from the U.S. War Department for the purchase of war surplus material and equipment, and a credit from the U.S. Shipping Board for the shipment of any material and equipment thus purchased, the Yugoslav Government failed to take advantage of either credit.

Before he left the United States for Yugoslavia, Atwood was instructed by the Minister of Posts and Telegraphs to purchase a list of material and equipment from War Department surplus stocks. As Atwood later explained it: "Minister Lukinitch stated that he had available the money to buy this material and requested me to get it, but I was not able to secure information as to where the money was or how to draw on it." Atwood, therefore, left the matter in the hands of the New York office with instructions to purchase the material "or material as nearly like it as possible" from War Department stocks once the War Department credit came through. The material was subsequently selected but no authority came from the Yugoslav Government for the purchase. The Minister of Communications also asked the technical mission to purchase thirteen locomotive cranes. Again, the necessary official authorizaion was not received until the cranes had been sold to others. Finally:

\footnotetext{
As all these articles were being sold rapidly, and, as I had received definite instructions from Minister Lukinitch to use our own judgment in selecting substitute material, the office proceeded to close a contract with the United States War Department as representing [the Yugoslav Government] for about $\$ 525,000.00$ worth of material. This contract is now repudiated by the Minister of Telegraph, apparently for the reason that the Engineers of the Department do not know the uses of the substitute material and have not enough experience to enable them to take advantage of it. ${ }^{27}$
}

The Yugoslav Government, therefore, was in the position of refusing to buy that which was available from War Department stocks and continuing to press for the purchase of that which was not available. On June 23rd, the New York office cancelled all orders it had placed in behalf of the Yugoslav Government. ${ }^{28}$ The result was that the Yugoslav Government obtained very little benefit from the success of the technical mission in obtaining the requested credits.

Aside from its assistance in opening negotiations with Greece

${ }^{27}$ Atwood to Yugoslav Minister of Finance, June 18, 1920. ETA Papers.

${ }^{28}$ Memorandum from Rickard, June 23, 1920. ETA Papers. 
for the reestablishment of railroad traffic between Belgrade and Athens, the technical mission contributed very little to the restoration of international transportation services, the reason being, as Atwood explained it, that the technical advisers "were not furnished any information by the Minister of Communications nor did he request their assistance." ${ }^{29}$ The mission pressed considerable advice on the Ministry of Mines, based on extensive surveys of existing and potential mining sites, but its recommendations were little heeded. As for the instruction that the mission should advise the Ministry of Finance, Atwood conferred with a number of American bankers and corporations doing business in Europe concerning the possibility of the Yugoslav Government securing commercial loans in the United States. However, the Ministry of Finance apparently changed its mind on the question of obtaining American financial assistance and did not follow up on the information Atwood furnished it. The only request for assistance of any importance from the Ministry of Finance came in connection with the possibility of placing a concession in the United States for the development of the Ljubija iron mine and the construction of a steel plant. Inquiries by the technical mission led to some interest on the part of American enterprises, but nothing resulted. ${ }^{30}$

The principal duties of the technical mission, therefore, continued to be those for which the Transportation Section had been primarily responsible during the armistice-acting as advisors to the Ministry of Communications on railway problems. The Ministry furnished two railway cars to the technical mission and these were "in almost constant service" during the life of the mission, furnishing the means by which the advisers could survey the railroad system. Immediately after the return of advisers from such inspection trips, reports were made to the Minister of Communications concerning items of interest and containing recommendations by the advisers. All told, some fifty such reports were submitted to the Ministry. Recommendations were made concerning repairs to the lines, improvements in shop and engine-house facilities, operating methods on the railways, and proposed new lines. ${ }^{31}$ One new line suggested, from Belgrade to the Adriatic port of Cat-

${ }^{29}$ Atwood, "Report of the Technical Mission." ETA Papers.

${ }^{30}$ Loc. cit.

"Loc. cit. 
taro, was approved by the Ministry in late $1920 . .^{32}$ Atwood was ever alert to possible opportunities for American capital and American sales. Before he left the United States for Yugoslavia he conferred with engineering firms in the United States, and with officials of Western Electric, concerning the possibility of a telephone and telegraph franchise in Yugoslavia. The Yugoslav Government of late 1919 seemed interested, while doubting that such a concession was possible under the Berne Convention. ${ }^{33}$ The main thing, however, in Atwood's mind was that the Yugoslav telephone and telegraph system should be modernized, since it would be Western Electric equipment that would be used no matter who did the work or operated the system. However, it seemed more desirable for the modernization to be undertaken as a concession so as not to put "any further strain on the financial resources of the country. . . " ${ }^{34}$ Early in 1920 Atwood proposed to the Minister of Posts and Telegraphs that he should initiate such a modern communications system based on the latest inventions. There were two methods, he told the minister, by which the government could provide such a system. The Yugoslav Government could construct it, investing about $\$ 15$ million and employing American engineers "to design and superintend the construction and operation of the system because this new apparatus and the new methods are almost entirely of American invention and manufacture." Or, they could "give a franchise to a company-necessarily American-to construct and operate the wire lines." Atwood suggested that J. G. White \& Company, an American engineering firm, be encouraged to organize a company in connection with Western Electric and a group of financiers to carry through such a project. He had, he told the minister, had conferences with $\mathrm{Mr}$. White, with bankers, and with representatives of Western Electric and "found them favorably disposed toward such an investment." ${ }^{35}$ The Minister of Posts and Telegraphs in the new cabinet, however, was not interested. ${ }^{36}$ Moreover, the evidence of political instability in Yugoslavia had

${ }^{32}$ New York Herald. November 3, 1920.

${ }^{33}$ Atwood to J. G. White, December 20, 1919. ETA Papers.

${ }^{34}$ Atwood to Coe, November 12, 1919. ETA Papers.

"Atwood to Mr. Lukinitch. Minister of Posts \& Telegraphs, February 7, 1920. ETA Papers.

so Atwood to W. E. Leigh, February 19, 1920, ETA Papers. 
cooled the interest of J. G. White and Company, which now expressed disinterest in Yugoslavian investments until that country had "settled down into its normal life, has demonstrated that its Government is stable and that it will treat foreign investments fairly. ..." 37

Undiscouraged, Atwood continued to seek to interest American capital in Yugoslavian projects. To United States Steel he suggested that the extension of credits would secure for that company numerous contracts for the replacement of railway and highway bridges in Yugoslavia. ${ }^{38}$ To the New York office he suggested that J. G. White or some other engineering firm be encouraged to investigate the possibility of a franchise for a tramway between Belgrade and Zemun. The New York office, however, could stimulate no interest in the project. ${ }^{39}$ Nor could Atwood interest anyone in the construction of Yugoslavian hydro-electric plants unless that construction was to be paid for "in American gold, because this is the only kind of money that means anything to us these days. ${ }^{40}$ In mid-March the New York office wrote Atwood that the proposals he was submitting to them for consideration by capitalists or by engineering companies would be interesting to them only if accompanied "by valuable concessions or secured . . by mines or other real values. . . "41

Once Atwood turned to mining properties he attracted somewhat more interest, but.scarely any more action. When he informed New York of a coal proposition involving "good grade lignite suitable [for] strip mining," the Matthew Addy Company of Cincinnati at least expressed some interest in further details. ${ }^{42} \mathrm{On}$ April 7th the technical mission offered to New York what seemed the best opportunity either for development as a concession or as collateral for loans-the Ljubija iron mine in Bosnia, one of the richest mining properties in the kingdom. Colonel Coe described it as covering an area 40 kilometers long and 34 kilometers wide

3'J. G. White to Rickard, March 2, 1920, ETA Papers.

${ }^{38}$ Atwood to Victor G. Thomassen, February 19, 1920, ETA Papers.

${ }^{39}$ Atwood to Poland, February 27, 1920, ETA Papers; J. G. White to Rickard, March 2, 1920, ETA Papers.

${ }^{40}$ George W. Bacon to Atwood, March 9, 1920, ETA Papers.

4 Rickard and Poland to Logan for Atwood, March 15, 1920, ETA Papers.

${ }^{42}$ Atwood to New York office, March 19, 1920; James A. Green to Poland, March 27, 1920; Poland, March 27, 1920; Poland to James A. Green, April 1, 1920, ETA Papers. 
and estimated its potential at a half-billion British pounds sterling. ${ }^{43}$ On April 16th he forwarded additional mining reports to New York with the comment that "the best chance for capital investment at the present time is in mines," and that there had been a number of people there looking for concessions, most of them Englishmen. ${ }^{44}$ Meantime, Edgar Rickard was providing the American International Corporation with some of the mining propositions he had been receiving from Atwood. On April 3, 1920, he wrote John Power Hutchins of the AIC concerning a chromium deposit Atwood had suggested, asking if the AIC might be interested. "We have technical advisers also to the Polish, Austrian and Czech governments," he informed Hutchins. "Atwood is particularly active in sending us information of this character. The others would also, if encouraged. We are in daily communication by cable if you want further information. We have on file a choice assortment of other projects." 45 On April 19th he was invited to lunch with Hutchins and a number of senior executives of the American International Corporation. ${ }^{40}$

The American International Corporation was not interested in the chromium mines, however, nor in any other proposition yet offered by the technical missions. They were delighted at the

\begin{abstract}
opportunity afforded us by Hutchins to come into closer contact with your work to enjoy the benefit of such suggestions for the investment of American capital as may come to you from time to time through Technical Advisers. It is unnecessary to stress the fact to you that general conditions in this country make it extremely difficult to take advantage of the many opportunities for investment which must constantly arise in Europe. Nevertheless, we will appreciate a continued interest on your part even though, as in this specific case, we are unable to give favorable consideration to these suggestions. ${ }^{47}$
\end{abstract}

As for the Ljubija mine, Hutchins' own research revealed a more modest estimate of the area's iron ore reserves-an estimated amount which was "not brilliant" in its prospects. ${ }^{48}$ With Hutchins" approval the New York office wired Coe in Belgrade that "unless conditions for acquiring control Ljubija iron mine and

${ }^{93}$ Coe to New York Office, April 7, 1920, ETA Papers. Papers.

${ }^{14}$ Atwood to Logan, April 16, 1920; Atwood to Rickard, April 16, 1920, ETA

${ }^{45}$ Rickard to Hutchins, April 3, 1920, ETA Papers.

${ }^{16}$ Hutchins to Rickard, April 20, 1920, ETA Papers.

${ }^{47}$ William Franklin Sans to Rickard, April 24, 1920, ETA Papers.

${ }^{18}$ Hutchins to Rickard, April 22, 1920, ETA Papers. 
proven volume brilliantly attractive there is little chance of interesting Americans. However, American International prepared to learn details and discuss terms." Hutchins was en route to Paris via London, to arrive in mid-May. Poland and Rickard suggested that Coe discuss the matter with him then. ${ }^{49}$ However, Hutchins was so little interested in the project that he did not feel justified even in traveling to Belgrade to investigate it. ${ }^{50}$ Nor was he moved by the news from Atwood that an Anglo-French syndicate was "trying to get posssession of the property on a concession basis" and that there was an immediate market for the ore in Czechoslovakia and in France and England. ${ }^{51}$ Stymied in their search for foreign capital to develop the Ljubija mines, the technical advisers now found that the Yugoslav Government, too, was not "so anxious to use this concession as a basis for a loan as the former Cabinet had been." 52

While Atwood continued to try to interest American International Corporation and others in carrying out projects in Yugoslavia, his efforts were to no avail. Early in June, William B. Poland wrote Atwood from the New York office that he hoped he wouldn't

be discouraged over the lack of interest which we have been able to stir up in the [Yugoslav] projects. Your industrial and mining reports are interesting and valuable and are being classified and put in shape to present to any other that we think may be induced to give them attention. The fact of the matter is that just at the moment no one will investigate any overseas projects. The feeling is that the condition is too uncertain, and there is such an enormous demand for money in the United States that there is little inducement to go abroad with it. However, these conditions are likely to change at any time and banks and other people tell us that they want to be kept in touch with the situation and hope to be able to take an active interest later on. ${ }^{53}$

"Later on," however, was to be too late where the Yugoslav technical mission was concerned. The next month Atwood pressed the Yugoslav Government for a decision on whether the technical mission was to be continued under financial arrangements to be

${ }^{49}$ Poland and Rickard to Coe, April 23, 1920, ETA Papers.

${ }^{50}$ Hutchins to Logan. April 6, 1920, James A. Logan Papers, Hoover Institution on War, Revolution and Peace, Stanford, California; Logan to Atwood, June 3, 1920, ETA Papers.

${ }^{51}$ Atwood to Hutchins, June 5, 1920, ETA Papers.

${ }^{52}$ Memorandum of Interview at Office of Minister of Mines, June 8th-Belgrade. June 9. 1920," ibid.

${ }^{53}$ Poland to Atwood, June 7, 1920, ibid. 
made by that government. But Atwood, in pressing for an answer concerning the continuation of the mission, also gave voice to his complaints concerning the failure of the Yugoslav Government to make adequate use of the services of the technical advisers. Wrote Atwood to the Yugoslav Prime Minister:

The Advisory Staff does not feel that the Royal Government has received the benefit from their services that it should have had during the past year. The various Ministers have not called upon the advisers to the extent which the advisors desired them to. and the Advisory Mission has, therefore. not been able to do the things for which it was fitted and for which it had been employed, although many requests were made of the Ministers for the opportunity to do this work. It is hoped that if the Royal Government decides that it desires the continuation of the work of the Advisory Mission a greater use will be made of the service of the Advisors. Otherwise. it will be difficult to secure the services of any of the present Staff on account of the dissatisfaction with the amount of work which they have been permitted to do. If. therefore, the Royal Government decides to continue the Mission it should be with the understanding that a greater use will be made of the Mission in the ensuing year. ${ }^{54}$

The Yugoslav Government did not immediately reply. When it did, the reply was in the negative, though the Yugoslav Government did express its "great gratitude for work accomplished. . . ." 55 Arrangements were made to close up the mission by the first of September.

As the mission was being closed down in early September, Herbert Hoover wrote Atwood:

Poland and Rickard have reviewed to me the [Yugoslav] position and I have great sympathy with you in the trials and tribulations which you have confronted with such a fine spirit. It is a shock to us to find that the Serbians in their distressed condition, should not take full advantages of the services which you placed at their disposal. Under these circum. stances for your own professional record as much as our protection it is very essential you prepare carefully a report covering your activities and the constructive suggestions which you placed at the disposal of the [Yugoslav] Government. ${ }^{56}$

The technical mission to Yugoslavia was certainly the least successful of the four missions established in eastern Europe by Hoover's American Relief Administration. The other three missions lasted longer and accomplished a good deal more. Some confusion seems to have resulted from the failure of both Atwood and the Yugoslavs to understand that the purpose of the techincal

\footnotetext{
${ }^{54}$ Atwood to Prime Minister Vesnitch. July 23, 1920, ibid.

${ }^{55}$ Logan to New York Office, August 9, 1920, ibid.

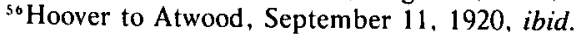


mission was to advise the Yugoslav Government-as employees of that government whose fundamental concern must be the interest of Yugoslavia-that the mission was not in Belgrade to represent the United States, or American or other interests. ${ }^{57}$ As James Logan wrote Rickard from Paris,

Atwood . . . always has too much the "mission idea" in his mind that ... may have lost considerable confidence with the [Yugoslav] Government. . . I have written repeatedly that he is not a mission and that his sole interest should be directed in the interests of the [Yugoslav] Government. who are paying him. ...

That Logan's arguments had had little effect is indicated by his closing comment, "It is pretty hard to drive a nail in oak." ${ }^{88}$ It was perhaps Atwood's view of the technical advisers as an American mission to Czechoslovakia that led him to spend so much of the advisers' effort on seeking to advance the penetration of American capital into Yugoslavia.

Nevertheless, a good deal of the technical mission's effort was directed toward advising and assisting the Yugoslav Government in post-war reconstruction. And in Poland, Austria, and Czechoslovakia this was even more the case. When taken in conjunction with the relief functions of the ARA during this same period through such agencies as the European Children's Fund, it is apparent that Professor Warren's comment that Hoover was running a kind of UNRRA during the armistice period remained true to a slightly lesser degree for some time even after the signing of the peace treaties. Professor Harold H. Fisher has remarked on the similarity between the activities of Hoover's technical missions in eastern Europe and the Point Four program for lesser developed nations under President Truman. ${ }^{59}$ One might also view the coal commission as a forerunner of the cooperative approach to European coal and other economic problems that found fuller expression after World War II, beginning with the European Coal and Steel Community.

While the Yugoslav technical mission ended in September, 1920, the others continued in operation, serving the nations to which they were attached for periods varying from two to four

${ }^{57}$ Atwood at Logan, March 1, 1920, ibid.

${ }^{58}$ Logan to Rickard, April 23, 1920, ibid.

${ }^{59}$ Conversation with the author, August, 1971. 
years. When Hoover entered the Harding Cabinet in March, 1921, however, he severed his connection with the technical missions, designating Poland and Rickard as trustees for the remittance funds in his place. William B. Poland resigned in 1922, the same year that the technical mission to Poland came to an end, and the technical mission to Austria ended the following year ${ }^{60}$ It is to be hoped that the full impact of Hoover's technical missions on the reconstruction of eastern Europe will before long be assessed by historians dealing with that part of the world.

${ }^{\circ}$ Van Patten, “The European Technical Advisers," I, 312; II, 395.

* * *

\section{Book Reviews}

The Hoover-Wilson Correspondence, by Francis William O'Brien. Ames: Iowa State University Press, 1974. pp. xxvi, 297.

There can be little doubt that Herbert Hoover, even forty years after his departure from the White House, still constitutes one of the greatest mysteries of the American twentieth century. Fortunately, Francis William O'Brien's The Hoover-Wilson Correspondence provides historians with a compact collection of primary source materials which shed light on Herbert Hoover and clarify some of the historical confusion and ignorance still surrounding his pre-presidential career. O'Brien has compiled 201 letters written by Hoover to Wilson, and 97 letters from Wilson to Hoover, all of them drafted between September 24, 1914 and November 11, 1918. Brief but effective commentaries composed by Mr. O'Brien accompany the letters and place them into a proper context and perspective.

The letters comprising the book are almost exclusively concerned with the economic and political difficulties Hoover encountered during World War I as he directed the Commission on Belgium Relief and the Food Administration. The letters from Hoover often explicitly detail his opinions, while Wilson's responses are for the most part brief acknowledgements or agree- 
Copyright of Annals of Iowa is the property of State of Iowa, by \& through the State Historical Society of Iowa and its content may not be copied or emailed to multiple sites or posted to a listserv without the copyright holder's express written permission. However, users may print, download, or email articles for individual use. 